\title{
総説 REV䁘W
}

\section{生物多様性保全のための河川における侵略的外来植物の管理}

\section{宮脇 成生 $^{1)}$ ・熟谷 $\left(\right.$ いづみ ${ }^{2)}$}

1）株式会社建設環境研究所 $\bar{T}$ 170-0013東京都豊島区東池袋2-23-2

2）東京大学農学生命科学研究科 $\bar{\tau} 113-8657$ 東京都文京区弥生 1-1-1

Shigenari MIYAWAKI ${ }^{1)}$ and Izumi WASHITANI ${ }^{2}$ : Management of invasive alien plants in riparian habitats of Japan for biodiversity conservation.

Ecol.Civil Eng. 6(2), 195-209, 2004.

1) Civil Engineering and Eco-Technology Consultants Co., Ltd, 23-2,

Higashi-Ikebukuro 2-chome, Toshima-ku, Tokyo 170-0013, Japan

2) Institute of Agricultural and Life Sciences, University of Tokyo, 1-1-1, Yayoi, Bunkyo-ku, Tokyo 113-8657, Japan

\begin{abstract}
Native riparian plant communities are profoundly threatened by invasions of alien plants in Japan. At present, the proportion of vegetation area dominated by alien plants accounted for about 15 percent in the rivers administrated by the Ministry of Land Infrastructure and Transport. Displacement of native plant communities by invasive alien plant species is altering riparian ecosystems substantially. To preserve riparian plant communities, active management to suppress the dominance of invasive alien plants is urgently required. Weed control methods in agricultural ecosystems, which usually have strong side effects on various organisms and tend to simplify the ecosystem, are not suitable for the control measures for biodiversity conservation. Ecosystem approaches, focusing both management of invasive species and restoration of sound ecosystems simultaneously are desirable. Ecosystem management on the invasive species populations and habitat restoration should be based on sufficient information on the population ecology, and the causal factors enhancing ecosystem invasibility.
\end{abstract}

Key words: adaptive management, alien plant control methods, catchment area strategy, invasive alien plants, riparian habitats

\section{はじめに}

過去 100 150 年の間に交通機関の発達や経済活動の グローバル化に伴う人や物資の移動が活発になるととも に，それに伴う生物学的侵入が頻繁に起こるようになり

(di Castri 1989; Ashton \& Mitchell 1989), 河川において も在来植物のみで構成される植生は現在まれになった (Cronk \& Fuller 1995). 日本の河川も例外でなく, 多く の外来植物の侵入をみることができる. 1999 年の時点で,

2003 年 5 月 14 日受付, 2004 年 1 月 16 日受理

1) mivawaki@kensetsukankyo.co.jp
国の各直轄河川（109 水系 123 河川）で確認された植物 種の 1 〜 割が外来植物で占められるまでになっている (外来種影響・対策研究会 2001; 鷲谷 2002a). 河川への外来植物の侵入は，生態系だけでなく人間の 健康や産業活動にまで様々な負の影響を及ぼす（日本生 態学会 2002)。それらの悪影響を回避し，健全な河川環 境を保全するためには，河川管理の現場においても外来 植物への対策が必要である（外来種影響・対策研究会 2001 ; 国土交通省北陸地方整備局千曲川工事事務所 2003).しかし，日本の河川に拈ける外来植物の生態に関 する情報は限られているため, 外来植物が問題となって 
いる現場において，適切な生態の研究にもとづいた駆除 方法等の検討を行う必要がある.

本稿では，日本の河川に扔ける外来植物の侵入状況お よびその影響，効果的な外来植物対策を実施するための， 流域を視野においた管理戦略㧍よび戦術（駆除方法）に ついて，保全生態学の立場，すなわち，生物多様性と健 全な生態系の保全（䃣谷 1999）を目指すという立場から， 筆者らの公表済みの研究成果，河川水辺の国勢調査など 既存データの分析などを交えながら概説する。

\section{日本の河川における外来植物の侵入状況}

日本の河川に拉ける外来植物侵入の概況は,「河川水辺 の国勢調査」の結果から把握することができる。「河川水 辺の国勢調查」は，平成 2 年度より建設省（現国土交通 省）が全国 109 水系の直轄河川 123 河川で実施しており， その一環で「植物調査」として各河川の直轄管理区間に おいて，およそ 5 年に 1 回の間隔で植物相の調査および 植生図の作成が行われている（建設省河川局河川環境課 1997c).

河川別に作成された植生図から，植生区分ごとに合計 面積が算出されている(建設省河川局治水課 1994，1995； 建設省河川局河川環境課 1996，1997a，1997b, 1998，1999，2000；国土交通省河川局河川環境課 2001）. それにもとづき，外来植物が優占する植生(以降，「外来 植物群落」と記す）の面積扔よび各河川の全植生面積を 集計した，集計対象としたのは，平成 3 年度（1991 年） から平成 11 年度（1999 年）の期間に実施された調査の うち, 各河川の最新の結果である。な扔, 外来植物群落 としては，植生図に抢ける植生区分名（群落名）に外来 植物種名が含まれているもののみを取り上げた，外来植 物種名は「日本の外来種リス卜 (維管束植物)」(日本生 態学会 2002）に従って表記した。

集計の結果，平成 3 年度から平成 11 年度までの調査 で確認された外来植物 444 種（外来種影響・対策研究会 2001)のうち 87 種について，その種が優占する群落が確 認された，それら外来植物群落面積の調査河川に扔ける 合計は約 12000 haに達し,これは全植生面積の約 $15 \%$ に あたる．河川別にみると，植生において外来植物群落が 占める面積の割合は平均值で約 $17 \%$ だった（Fig. 1 ）。 なお, 植生の $50 \%$ 以上が外来植物群落で占められている 河川として, 中川(綾瀬川を含む), 猪名川, 草津川, 白 川，肝属川の 5 河川が確認された。

外来植物群落を優占種別にみると, 全調査河川での合 計面積が 100 ha 以上となるものは 18 タイプが確認され

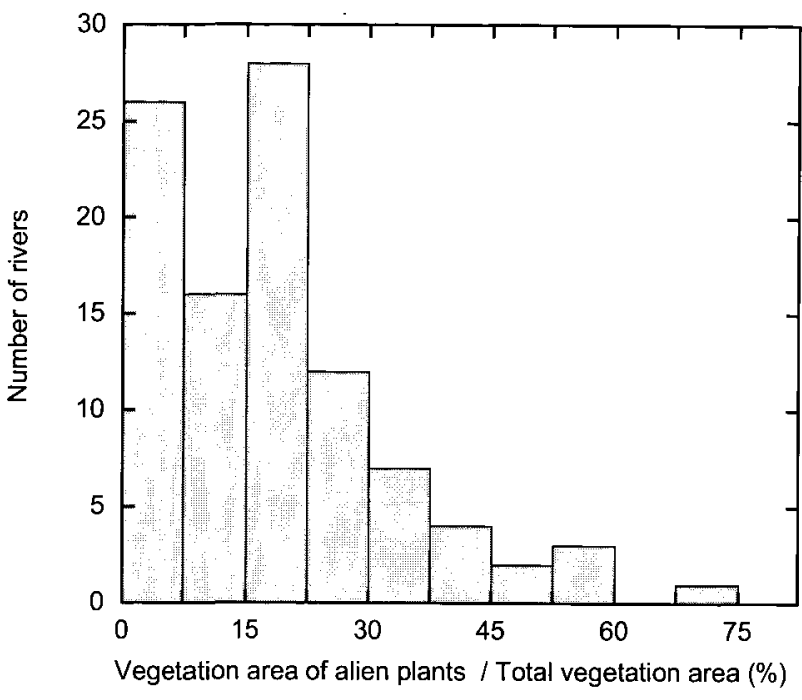

Fig. 1. Frequency distribution of $\%$ vegetation area dominated by alien plant species in the total vegetation area among 123 rivers in Japan.

た（Table 1)．この18タイプの合計面積は，全外来植物 群落面積の約 $90 \%$ を占めていた（Fig. 2 )。圧倒的な優 占を誇るのが多年生草本のセイタカアワダチソウ Solidago altissima $\mathrm{L}$., 木本のハリエンジュ（ニセアカシア） Robinia pseudoacacia L., 次いでカモガヤ Dactylis glomerata L.，オオブタタサ Ambrosia trifida L., オオアワダチ ソウ Solidago gigantea Aiton var. leiophylla Fernald であっ た。これらのみの合計で，全外来植物群落面積の拉よそ 3 分の 2 である $64 \%$ 占めていたこの上位 5 タイプの 優占種はすべて “日本の侵略的外来種ワース卜 $100 ”(日$ 本生態学会 2002）に挙げられた種であった。“侵略的外 来種 (invasive alien species)” とは, 外来種のうち, 導入 もしくは搪散した場合に，生物多様性を妿かす種を指す (UNEP 2002; 日本生態学会 2002). “日本の侵略的外来 種ワースト100”に選定されているものも，日本に扔い て生態系や人間活動への影響が大きく，優先的に対策を 行うべき外来種である（日本生態学会 2002）.

なお以上の集計では，「牧草地」「採草地」「人工草地」 といった主に外来牧草で占められる領域を含めていない ため, 外来植物群落の合計面積抢よび外来牧草（ネズミ ムギ Lolium multiflorum Lam.，カモガヤ等）の面積を過 小評価している。「牧草地」「採草地」「人工草地」の合計 面積は約 18,000 ha であり，この値は先述の外来植物群 落の合計面積を上回っている。 
Table 1. Total area occupied by vegetation dominated by alien plant species over investigated rivers. Only those with the area above 100ha are presented. Total investigated area accounted for about 81 thousand hectares in the rivers administrated by the Ministry of Land Infrastructure and Transport.

\begin{tabular}{|c|c|c|c|}
\hline \multirow{2}{*}{$\frac{\text { Family }}{\text { Compositae }}$} & \multicolumn{2}{|c|}{ Dominant species of vegetation } & \multirow{2}{*}{$\frac{\text { Vegetation area (ha) }}{3369}$} \\
\hline & セイタカアワダチソウ & Solidago altissima $\mathrm{L} . *$ & \\
\hline Leguminosae & ハリエンジュ & Robinia pseudoacacia $\mathrm{L} . *$ & 2197 \\
\hline Gramineae & カモガヤ & Dactylis glomerata $\mathrm{L} . *$ & 835 \\
\hline Compositae & オオブタクサ & Ambrosia trifida $\mathrm{L}^{*}$ & 603 \\
\hline Compositae & オオアワダチソウ & Solidago gigantea Aiton var. leiophylla Fernald* & 579 \\
\hline Gramineae & セイバンモロコシ & Sorghum halepense (L.) Pers. & 550 \\
\hline Compositae & ヒメムカショモギ & Evigeron canadensis L. var. canadensis & 386 \\
\hline Gramineae & シナダレスズメガヤ & Eragrostis curvula (Schrad.) Nees* & 379 \\
\hline Cucurbitae & アレチウリ & Sicyos angulatus L** & 319 \\
\hline Compositae & オオアレチノギク & Conyza sumatrensis (Retz.) Walker* & 254 \\
\hline Leguminosae & イタチハギ & Amorpha fruticosa $\mathrm{L}$ * & 230 \\
\hline Gramineae & オオクサキビ & Panicum dichotomiflorum Michx. & 216 \\
\hline Compositae & コセンダンダサ & Bidens pilosa L. var. pilosa & 151 \\
\hline Gramineae & メリケンカルカヤ & Andropogon virginicus $\mathrm{L}$. & 134 \\
\hline Gramineae & ナガハグサ & Poa pratensis L. var. pratensis & 132 \\
\hline Gramineae & タチスズメノヒエ & Paspalum urvillei Steud. & 124 \\
\hline Hydrocharitaceae & オオカナダモ & Egeria densa Planch* & 121 \\
\hline Gramineae & アメリカズズメノヒエ & Paspalum notatum Flügge. & 115 \\
\hline & & All alien plant species & 11882 \\
\hline
\end{tabular}

*100 of The Worst Invasive Alien Species in Japan (The Ecological Society of Japan 2002)

\section{河川における外来植物侵入の影響}

外来種の侵入は，生物多㥞性に対して大きな劦威とし て認識されている (Primack 1993; 槩谷・矢原 1996 ; McNeely et al. 2001; Wittenberg \& Cock 2001; 環境省 2002). また，植物は陸域から水域の生態系に扔いて生物群集の

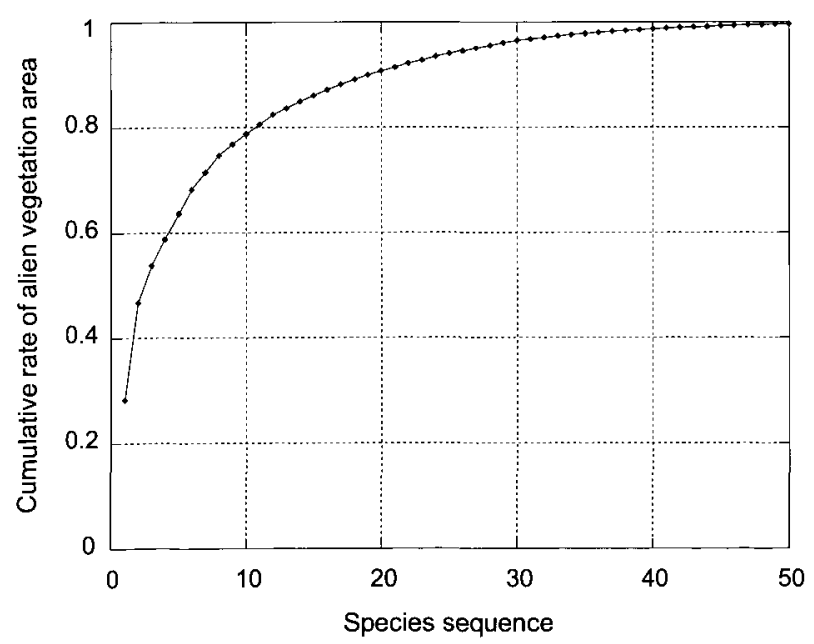

Fig. 2. Cumulative proportion of total vegetation area dominated by alien plant species for top 50 species.
骨格を成しているため，多様な在来植物で構成されてい た植生が，外来植物で優占される植生で置き換えられる ことは，生態系が全く異質なものに変化することを意味 する (Schmitz et al. 1997; Blossey 1999).

外来植物が侵入先の生物多様性や生態系に与えた影響 に関しては，すでに世界中から多くの報告がなされてい る(例えば, Mooney \& Drake 1986; Drake et al. 1989; Mooney \& Hobbs 2000; 日本生態学会 2002). 外来植物が与之 た明瞭な影響としては，水文パターンの変化（van Wilgen \& Richardson 1985; Busch \& Smith 1995; Le Maitre et al. 1996), 土壤中の栄養塩類濃度の变化 (Vitousek 1986; Vitousek et al. 1987; Busch \& Smith 1995), 土砂堆積の促 進 (MacDonald et al. 1989; Busch \& Smith 1995; 中坪 1997), 在来植物との置き換わり (Ewel 1986; Busch \& Smith 1995; Gould \& Walker 1997), 在来種の成長抑制（Wilson 1989; Matsumoto et al. 2000) などが挙げられている.

日本の河川においても，外来植物の侵入により，河川 固有の植物の存続が危ぶまれるようになった事例（村中． 熟谷 2001 b), 植物種の多様性が減少している事例(宮脇· 熟谷 1996）などが報告されている（Fig. 3).

一方，外来植物侵入による高次の相互作用や間接的な 


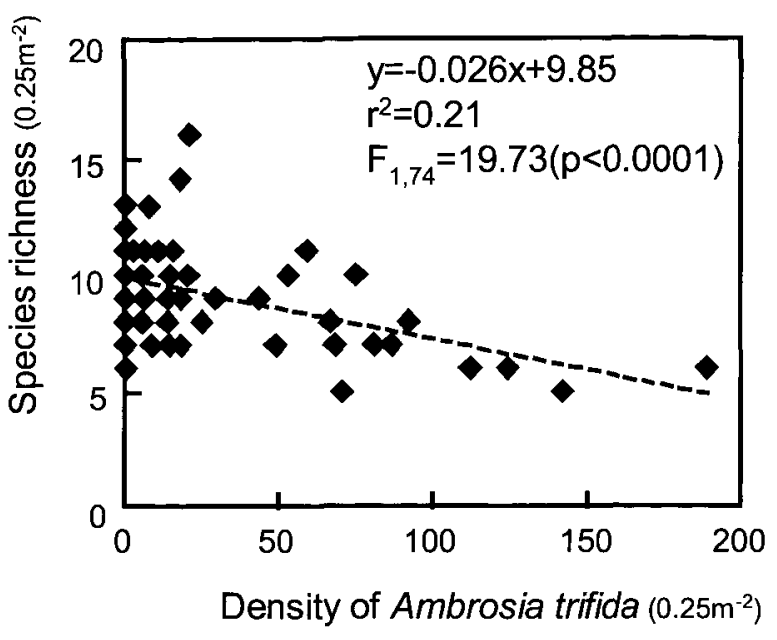

Fig. 3. Rerationship between species richness and the density of Ambrosia trifida in the Tajimagahara Nature Reserve. Species richness and density are defined, respectively, as the number of vascular plant species and the number of individuals of $A$. trifida in each quadrat of $0.25 \mathrm{~m}^{2}$. (Redrawn from Miyawaki \& Washitani 1996)

影響（例えば，生態系レベルでのエネルギーや物質循環 への影響，生物間相互作用への影響など）については， 研究例が少なく，その知見は極めて限られたものでしか ない (Mack \& D'Antonio 1998; Blossey 1999).

これらの外来植物の侵入が生態系に対して与える変化 は“不可逆的”である可能性を持つ（安島 2001; 鶞谷 2002a）. すなわち，一時的あるいは長期にわたる外来植 物個体群の成立は，地域に扔ける種子供給源の成立を意 味し，ここから供給される種子は土壤シードバンクとし

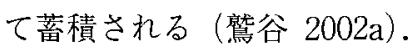

土壤シードバンクとは，土壤中あるいはリター層中に 存在する生存種子の集団をさす（Simpson et al. 1989; 荒 木ほか 2003)。土壤シードバンクは，その持続性にもと づいて，季節的シードバンク（seasonal seed bank）と永 続的シードバンク (persistent seed bank) に分類するこ とができる（Thompson \& Grime 1979; 荒木ほか 2003). 永続的シードバンクが存在する場合には，土壤シードバ ンクの消長と地上の個体群の消長は必ずしも一致しない. 種子の長い寿命に応じて地上の個体群が消失した後も， 土壤シードバンクは持続するからである (Leck et al. 1989).

したがって, 外来植物の土壤シードバンクは植生遷移 の初期相を本来とは全く異なるものに変化させる可能性

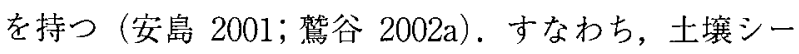

ドバンクが維持されていれば，たとえ遷移が進んでその 外来植物の群落が地上から姿を消したとしても，その場 所が擋乱を受けるたびにその外来植物が優占する可能性 がある (熟谷 2000b).

外来植物の河川への侵入は, 治水上の安全性にも影響 を及ばす場合がある(Busch \& Smith 1995)。例えば，河 道周辺の砂河原など, 本来, 植生密度が疎らで裸地的な 場所にシナダレスズメガヤ Eragrostis curvula (Schrad.) Neesのような外来牧草が密生した場合，あるいは草本や 低木の在来種が生育していた場所にハリエンジュのよう な高木が侵入し樹林を形成した場合，河道の洪水流下能 力にも影響が及ぶ可能性が大きい（例えば，清水・長田 2002).

また，外来植物の侵入は農業，林業などの経済活動に 対しても損失を与える (Mack \& D'Antonio 1998; Pimentel et al. 2000; Pimentel et al. 2001; 清水 2000). 日本の河川 の直轄管理区間における農耕地面積は，17000 ha 越え る（建設省河川局治水課 1995 ; 建設省河川局河川環境 課 1996，1997a，1997b，1998，1999，2000；国土交通省 河川局河川環境課 2001). 河川への外来植物の侵入は, これらの農耕地の生産性に直接的な影響を与えるだけで なく，農耕地における除草剂等の使用量の増加を通じて， 間接的に周辺の生物や河川の水質へ悪影響を及ぼす可能 性がある．畑等の農耕地に侵入して作物生産を阻害する いわゆる “害草”には，外来の草本植物も多〈含まれて いる（清水 2000）。また，炭疽病菌の宿主となることを 通じてハリエンジェやイタチハギAmorpha fruticosa L. がリンゴ等の果樹生産に病害をもたらすことも知られ ている（例えば，飯島 1999）。

河川の堤防などを外来のイネ科牧草（例えば，ネズミ ムギ Lolium multiflorum Lam., カモガヤ Dactylis glomer ata L., ヒロハウシノケグサ Festuca pratensis Huds. など) が覆っている場合，己れら風媒植物が大量に散布する花 粉が，周辺住民の花粉症の原因となることも知られてい る（斉藤・井手 1994）。これまでに多摩川や江戸川にお いて学童の集団花粉症発症の事例が知られている(齐藤・ 井手 1994). また，河川敷で大規模な群落を形成市るこ とのあるオオブタクサも風媒植物であり，同様に花粉症 の原因となる可能性がある（斉藤・井手 1994）.

\section{流域を視野においた外来植物管理戦略の必要性}

外来植物対策を成功させるには，生態学的な視点加 の適切な戦略が必要である.外来種の駆除あるいは管理 活動は世界各地で実施されているものの, 不適切な計 
画・方法による失敗例も報告されている（MacDonald et al. 1989; Randall et al. 1997; Simberloff 2003).これまでに, 外来植物の根絶に成功した例はそれほど多いとはいえな いが (Simberloff 1997)，その目標は原則的には根絶にお くことが重要である(Cronk \& Fuller 1995; 鷲谷・村上 2002)。なぜなら，根絶に成功すればその㣪の生物多様性 および生態系への影響や経済的な損失を回避できるが, ある水準で侵入拡大を抑制し続けるような制御の場合は， 生物多様性および生態系への不可逆的な影響と経済的な 損失が継続することになるためである (Wittenberg \& Cock 2001; 熟谷 2002a).

根絶を成功させるためには, 外来種侵入後の早い段階 で対策を開始することとともに，集中的に労力㧍よび費 用を投入することが必要である (Hobbs \& Humphries 1995; 鷲谷 - 村上 2002). 個体群が存続可能な程度の個体 数が駆除しきれずに残っていたり，継続年数が十分でな いなどといった不徹底な対策では, 効果が得られない可 能性が高い（例えば，宮脇・鷲谷 1996; Parker 2000).

また，たとえ対象とする外来植物を一旦根絶できたと しても, 再侵入の可能性があるため, 同時に侵入源への 対策が必要である (Usher 1988; MacDonald et al. 1989; Zavaleta et al. 2001).

一方，外来種対策自体が在来種および生態系に影響を 与える可能性についても考慮しなければならない(Zavaleta et al. 2001; 外来種影響・対策研究会 2001). すなわ ち, 外来種対策の計画策定に際しては, 駆除実施による 外来植物個体および個体群の反応だけでなく, 他の生物 および生態系が示す反応を把握する必要がある(Cronk \& Fuller 1995; 西廣·皆川 2002).

外来種対策に伴う影響には，いくつかのタイプが考え られる。例えば, 外来植物を駆除するために除草剤を使 用した場合，標的生物以外の生物への影響，食物連鎖を 通じた生物濃縮などの副次作用をもたらす可能性がある。 加えて, 特に河川での除草椷の使用は, 河川への流入に よる水質への影響が問題となる。

また, 複数の外来種が侵入している場合, 単に 1 種の 外来種を除去することは, 他の外来種にとっての生肓に 適した場所をつくり出すことになる可能性もある(Zavaleta et al. 2001). そのため, 多くの場合, 外来種対策は 1 種のみでなく, 複数種を対象に同時に進めることが必 要である (Hobbs \& Humphries 1995).

外来種の侵入状況によっては, 土壤中の栄養塩の組成 や濃度を在来種の生育に適さない状態に変えてしまい, 外来種を除去するだけでは生態系が回復しないこともあ
る(El-Ghareeb 1991)。このような場合は, 外来種の根 絶とともに, 生育条件の修復も必要となる (Randall et al. 1997; Myers et al. 2000; Zavaleta et al. 2001).

以上の問題に対処しつつ, 外来種の効果的な管理を行 うには，個別の種の駆除にのみ焦点を当てた戦術的なア プローチだけでなく，生態系を視野に入れた長期的かっ 広範囲の戦略が必要である (Simberloff 1997; Mack et al. 2000).このような戦略は, 目前の外来種に対処すること だけに集中するのではなく, 同時に何種もの外来種の侵 入および分布拡大をもたらしている要因を十分に把握し， それを取り除く根本的な解決をめざすものである

(Mack et al. 2000). また, 外来種対策を, それだけで単 独に実施するのでなく, 生態系の回復というより広い目 標のもとに位置づけることは, 生態系や生物多様性への 好ましくない影響を防ぐ上でも有効である（Zavaleta et al. 2001; 日本生態学会 2002). ただし, 生態系に対する 人為的な働きかけがもたらす影響の予測には限界がある

(鴐谷・松田 1998; 熟谷 1999). あらかじめ予期しない 影響に対応するためにも，河川における外来植物への対 策は，モニタリングを重視し，順応的管理手法(鷿谷 1998）により進める必要がある（鶦谷・村上 2002）.

これまでそのように生態系の問題を十分に考虑した， あるいは広範囲・長期を対象とした戦略にもとづいて実 施された外来植物管理の例はそれほど多くはなかった (Luken \& Thieret 1997). しかし，いくつかの国に扔い てはすでにこのような外来植物管理が始められている。 例えば，オーストラリアは，侵略的外来植物の影響を抑 制することを目的とした国家雑草戦略を策定して実践し ている (Agriculture and Resource Management Council of Australia and New Zealand et al. 1999). また, 南アフリ カ共和国では, 20 年計画ですべての侵略的外来木本植 物を伐採するプロジェクトを開始し，着実に成果を上げ つつある (The Working for Water Programme 2000, 2001， 2002).このプロジェタトは, 侵略的木本外来種の占有面 積が 170 万 haにも及び, それらが蒸散作用によって大量 に水を消費することを通じて, 流域の利用可能な水量を 著しく減少させている (van Wilgen \& Richardson 1985; Le Maitre et al. 1996; Le Maitre et al. 2000) という現状認 識にもとづくものでもある。このプロジェクトには年間 約 2 千万USドルが投資されているが，これは水供給を 確保するために大規模ダム建設する場合と比較して、は るかに低コストである（van Wilgen et al. 1998）。さらに， 外来植物の伐採という労働集約的な作業を多く要するこ とを通じて，新たな雇用を創出するとともに，最䝷層の 
生活を支援するといった面から社会的な意義も大きい

(The Working for Water Programme 2000; 2001; 2002).

\section{流域の外来植物管理戦略立案において考慮すべ き事項}

適切に侵略的外来植物の駆除を行うには，その生態学 的特性，とくに生活史および個体群動態に係る諸特性， 掠よび外来植物の侵入・分布拡大を助長するような環境 要因を十分に把握した上で管理計画を立てる必要がある

(Groves 1989; Curnutt 2000).

ここでは，流域での外来植物管理戦略を立案する際に 考慮すべき事項について, 河川への侵略的外来植物の侵 大をその 3 つの構成要素, すなわち “侵略的外来植物の 生態学的特性”, “河川の特性”, “人間活動”に着目して 述べる.

\section{（1）侵略的外来植物の生態学的特性}

駆除計画の立案においては, 対象となる外来植物の生 態的な特性や侵入場所での個体群動態を把握した上で, 有効な方法をとる必要がある(Cronk \& Fuller 1995; 第谷. 矢原 1996)。植物の個体群動態に関する分析や予測にお いては，「隐された地下の個体群」ともいえる土塨シード バンクを考慮に入れることが必要である（Kalisz \& McPeek 1992; 觜谷 1993; Silvertown \& Charlesworth 2001; Doak et al. 2002). 外来植物には, 摚乱依存的な生活史戦 略を持つものが多く，このような種の多くが永続的シー ドバンクを形成するからである (Grime 1979; 鷲谷・森本 1993)。そのため, 永続的シードバンクを形成する種の駆 除を行う場合，根絶のためには土壤シードバンクの持続 性に応じた継続的な取り組みが必要となる（宮脇・鷲谷 1996; Drayton \& Primack 1999).

外来植物に対する効果的かつ効率的な駆除方法を選択 する際には，個体群動態モデルを用いた個体群の将来予 測が有力なツールとなる（歶谷 1997; Byers et al. 2002）. 個体群動態モデルは, 絶滅危惧種の保全管理の結果を予 測するために多くの事例で使用されてきた（Menges 2000).外来種管理においても個体群の成長に対して重要 な生活史段階を明らかにし，その存続可能性を低下させ る対策を見出すためには，個体群動態モデルを用いた子 測が有効である（宮脇・竴谷 1996; Drayton \& Primack 1999; Parker 2000).

例之ば，宮脇・鷲谷（1996）は，荒川河川敷の特別天 然記念物保護区内に侵入したオオブタクサについて，土 壌シードバンクを考慮した個体群動態モデル（Fig.4） を用いたシミュレーションにより駆除効果の予測を行っ
た．その結果，保護区内のオオブタクサを根絶するため には，少なくとも発芽個体の $90 \%$ 以上を数年間継続的に 駆除しなければならないことが明らかになった（Fig. 5). その後, 同保護区では，徹底した外来植物駆除を継続的 に実施し効果を上げつつある（浦和市教育委員会 2001）. すでに河川の広範囲に生育している外来植物の管理に おいては, 対象種のメ夕個体群の構造とその動態を把握 しておくことが必要である。メ夕個体群とは，個体群間 を流動する個体や遺伝子によって相互作用をもつ，地域 に散在する個体群（局所個体群）のあつまりと定義され る (Hanski \& Gilpin 1996; 熟谷·矢原 1996)。一般に, 局所個体群の種子生産と分散により新たな局所個体群の 成立が保障されていれば，一部の局所個体群が衰退ある いは消失しても，そのメ夕個体群は存続する（Hanski 1999）。したがって，河川での外来植物侵入による影響を 抑制するためには，種子供給源をつくらないための対策 に加えて，すでに形成されている種子供給源を消滅させ るための管理が必要となる(鴜谷 2000a)。例えば，メ夕 個体群構造にソース個体群とシンク個体群（Pulliam 1988）の明暸な区別が認められる場合には，まずソース 個体群，すなわち十分な種子生産を示し，確実な実生の 定着が認められる個体群の種子生産を抑制することに重 点を置く必要がある(熟谷 2000a).

河川においては，流水によって植物体の一部や種子等 の繁殖体が下流へ分散されやすい(例えば, Staniforth \& Cavers 1976; Schneider \& Sharitz 1988).この流水による散 布は，新たな場所へ種子等を供給することで水辺の植生 の多様性維持に貢献する一方で, 外来植物の種子等の分 散にも寄与している (Campbell et al. 2002)。流水で運ば れる種子は，必ずしも水に浮く構造を持つものに限られ て扔らず，これらが増水時に運搬されたのち，到着した 場所に定着する事例が報告されている(米森・倉本 2000). このことは, 河川に外来植物が侵入した後の流域レベル での種子による分布拡大速度が, 流水による分散効果が ない場合に比べて，ずっと大きいものである可能性を示 唆する (鷲谷 2000a).

\section{（2）河川の特性}

河道改修, 砂利採取, 河道横断構造物の建設などに伴 い，河床の低下や河道の複断面化などの変化が生じてい ることが明らかになってきた(例えば，李ほか 1999；末 次ほか 2001; 末次 2002)。これに伴い碎河原の隇少, 高 水敷の冠水頻度低下に伴う樹林化の事例が多くの河川で 報告されている(例えば，李注か 1999; 萱場 2000; 清水 ほか 2000; 末次ほか 2001; 末次 2002)。 


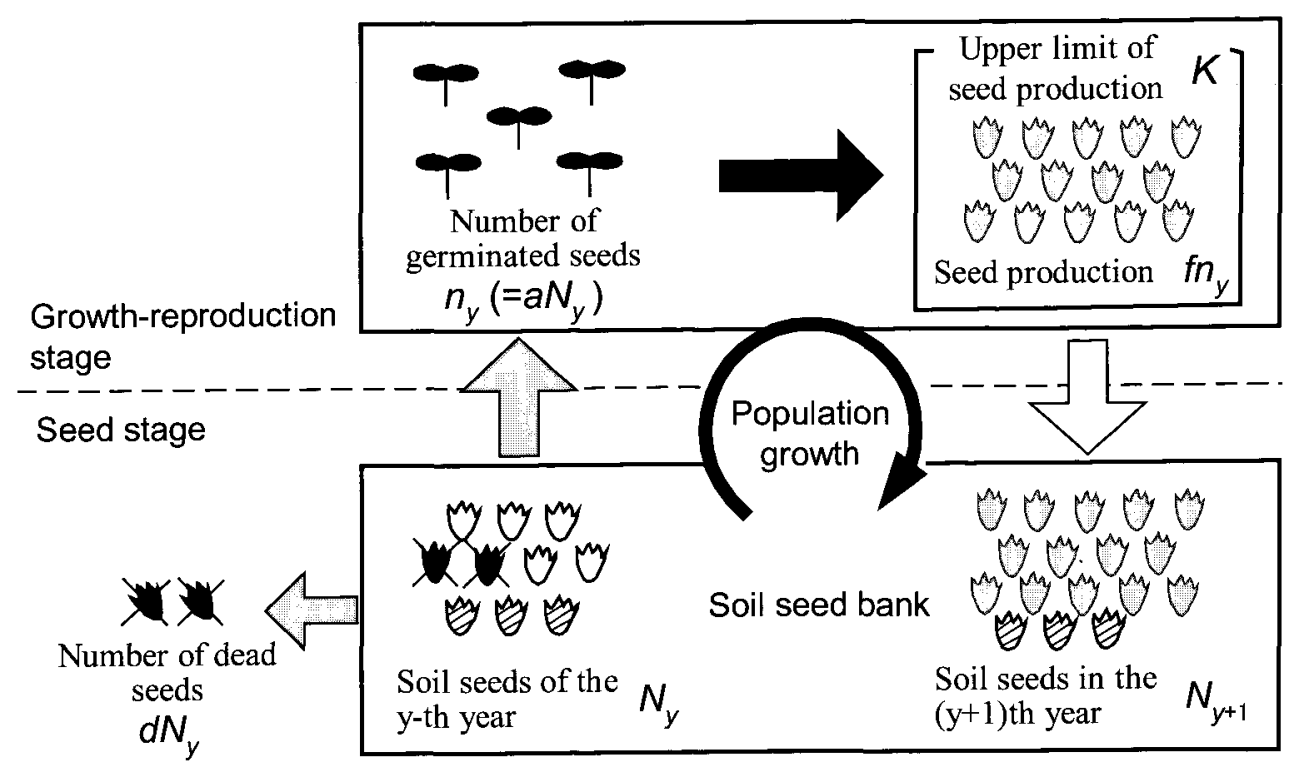

Fig. 4. Schematic representation of a simple model for population dynamics of A. trifida including soil seed bank components In this scheme, the number of seeds $\mathrm{N}$ in the $\mathrm{y}+1$ year is described as $N_{y+1}=$ Min $\left[K, f a N_{y}\right]+(1-a-d) N_{y}$ (Redrawn from Miyawaki \& Washitani 1996)

一方，河川に生育する植物種の分布あるいは種構成は， 地盤の水面からの高さ（Franz \& Bazzaz 1977; Lindsey et al. 1961; 倉本ほか 1993), 冠水頻度 (Conner et al. 1981; Johnson et al. 1976), 土壌の質 (Lindsey et al. 1961; 倉本 ほか 1993)などの要因の影響を受ける.これらの要因の 变化は, 河辺に生育する植物種の分布あるいは種構成に 対して不可避的に変化をもたらすこととなる（Busch＆ Smith 1995).

このような河岸地形の複断面化や高水敷の冠水頻度低 下は, 河川に固有な在来植物の生育適地を減少させる一. 方で，外来植物が侵入しやすい条件をつくりだすととも に，すでに侵入していた外来植物の分布掋大をもたらす 可能性がある (Kolar \& Lodge 2000). 例えば, 日本の河 川においても，河岸地形の複断面化とこれに伴う高水敷 の冠水頻度低下により，かつては裸地や疎らな草原であ った場所がハリエンジュなどの樹林に移行した事例が報 告されている(李ほか 1999; 末次ほか 2001; 末次 2002).

\section{（3）人間活動}

\section{1) 移入}

原产地から河川へ外来植物が到達するまでには，いく つかの段階がある。それぞれの段階における成否は，む しろそれぞれの植物が持つ生物学的特性よりも，人間活 動の諸相に依存するところが大きいと考えられている (di Castri 1989). 外来植物が河川に到達する経路には, “人間活動に伴う導入”と“河川周辺からの分布拡大”
がある（外来種影響・対策研究会 2001）。人間活動に伴 う導入には，利用目的に応じた“意図的な導入”，拉よび “非意図的な持ち込み”の 2 つの場合がある（村上・鷿 谷 2002).

河川における意図的な導入としては，お花烟造成(“フ ラワーベルト”, “フラワーカナル”などの名称で呼ばれ る)などの観賞目的の導入（外来種影響・対策研究会 2001), 牧草としての導入 (矢野 1988), 堤防法面の緑化 材料としての利用 (外来種影響・対策研究会 2001; 鷲谷 2002b)，水質浄化への利用（藤田ほか 2001）などが挙 げられる。

一方，非意図的な持ち込みには，輸入飼料・牧乾草な どに混入した外来植物種子を食べた家畜の糞の農耕地へ の肥料としての導入 (西田 2002), 河川工事等に伴う外 来植物種子の混入した土砂の持ち込み（外来種影響・対 策研究会 2001), 流域からの非意図的な種子分散などを あげることができる.

このような経路による外来植物導入の防止・抑制は, 定着個体数の抑制だけでなく，駆除後の再侵入を防ぐ点 からも重要である。特に, 緑化に用いられる外来植物に ついては，すでに多くの河川で大群落を形成し，大きな 種子供給源すなわちソース個体群が存在する。これらに 対しては，地域の在来種による緑化方法掞よび緑化材料 供給システムなどの早急な検討が必要である（日本緑化 工学会 2002). 


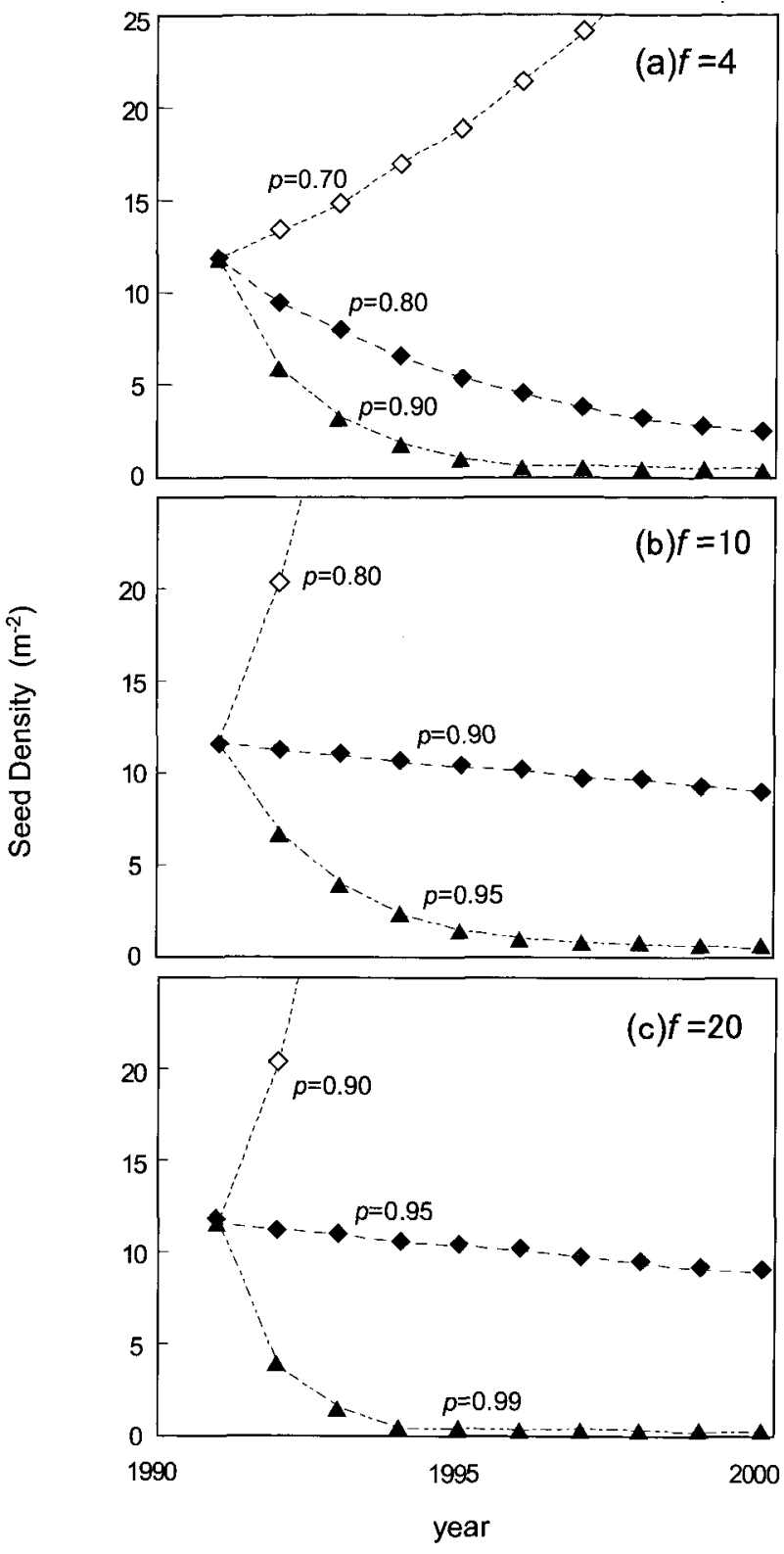

Fig. 5. Simulations of soil seedbank dynamics of A. trifida for propotion of removed individuals $(p)$ at different fecundity $(f)$ (Redrawn from Miyawaki \& Washitani 1996)

先進的な取組みとして六角川においては，国土交通省， 学識者等で組織される「在来種による河川緑化検討委員 会」により，六角川に生育する在来種による緑化資材供 給計画策定のための検討が，平成 14 年度（2002 年）よ り始まっている（外来種影響・対策研究会 2003）。

\section{2) 土地利用}

人間による土地利用パターンは，外来種による生態系 への侵入可能性に大きな影響を及ぼす (Hobbs 2000). 特
に農業や開発に伴う在来種のハビタットの分断化や摚乱 地の搪大は, 外来種の蔓延を助長する (Vitousek et al. 1996）。したがって，外来植物が侵入しやすい立地をつく らないように配慮することも，外来植物の分布拡大を抑 制する上では重要である。

現在の日本の河川では，ヨシ原やオギ原など既存の植 生が裸地化されると, 最初に侵入して優占するのは多く の場合，外来植物である。したがって河川敷での公園や 運動施設などの造成や，護岸工事などに伴う重機や資材 の置き場所確保などによる既存植生の破壊は，外来植物 の侵入に適した場所をつくることを意味する（Washitani 2001; 西廣 ·皆川 2002）。

\section{すでに河川に侵入した外来植物の対策}

河川に侵入した外来植物への対策の目的は，外来植物 による生物多様性，生態系および人間活動への影響を抑 制し，外来植物が侵入する前の環境を取りもどすことで ある。そのためには，河川に定着している外来植物の個 体数抢よび占有面積を減少させる必要がある。 その対策 に際しては，次のようなことを考慮すべきである。

\section{(1) 早期発見 ·早期対策}

根絶あるいは許容可能なレベルでの制御に成功した例 のほとんどは，外来種の侵入初期に対策・管理が始めら れたものである (MacDonald et al. 1989; Simberloff 2003). また，外来種の個体数がまだ少ない侵入初期に対策を開 始することは，外来植物侵入に伴う社会的コストを低く 抑えるために必須である (Hobbs \& Humphries 1995)。 し たがって，侵入初期においては，その種に関する生態情 報等が少なく，駆除手法に関する知見が不十分であった としても，何らかの駆除の取り組みを始めることが肝要 である (Simberloff 2003)。

外来植物の侵入初期に駆除を開始するためには，侵入 の初期段階で駆除すべき外来植物を検出するシステムが 必要である。現在，日本の直轄河川においては，5年に 1 回程度の頻度で実施される「河川水辺の国勢調査」で 植物相の調查および植生図の作成がなされているため, 比較的初期の外来植物侵入の検出が可能である。

すでにいくつかの河川に扔いて生育地の拡大がみられ， 何らかの問題を起こしている外来植物は（例えば, Table 1 ), 他の河川でも問題を起こす可能性をもっている。 そ れらがまだ侵入していない河川，あるいはまだ広い生育 地を占めるに至っていない河川に扔いて，これらを"警 戒種"として早期発見・早期駆除の対象とすることが望 まれる。 


\section{（2）優先的に駆除を実施すべき対象}

河川において外来植物駆除を実施するとき，上流から 下流までのすべての生育場所で同時に実施するのが理想 的であるが，現実的には様々な制約によって困難なこと も考えられる，その場合には，生物多様性保全上重要な 場所，あるいは流域からの外来植物根絶にとって効果が 高いと期待される場所から実施すべきである（Cronk＆ Fuller 1995).

生物多様性保全の観点から価值の高い場所としては, 絶滅危惧種およびその流域内で希少な種あるいは減少し つつある種の生育・生息場所や，在来種から構成される 良好な生物群集が残存している場所などが挙げられる (西廣・皆川 2002).

これに対して，その場所自体の保全上の重要性はそれ ほど高くなくとも，流域全体への影響を考慮したとき， 対策の優先順位を高くすべき場所もある（Hobbs＆ Humphries 1995). 前述のように, 河川では洪水時等の流 水による下流側への種子の運搬により，植物が分布を搪 げる可能性が高い。したがって，上流から再び侵入が起 こらないようにままず上流側の種子供給源となっている 個体群（ソース個体群）の対策に着手すべきであろう (鹑谷 2002a).

\section{（3）外来植物駆除方法の設定}

河川などの自然生態系で行う外来植物駆除の目的は, 対象とする外来植物の根絶や抑制だけでなく，地域の生 物多様性を維持すること，あるいはこれを回復すること である (Groves 1989)。これは，農地でおこなわれる雑 草管理と大きく異なっている点である．農地での雑草管 理は, 目的作物のみの生育に資するように, 生物相を単 純化する（Groves 1989）。また，そのほとんどが，空間 的にごく限られた範囲を対象とする(Hobbs＆ Humphries 1995). 生物多様性保全のための駆除において は, その方法が対象とする外来植物のみに選択的な効果 を持つとともに，駆除活動自体が人間を含めた他の生物 および生態系に影響を及ぼすことがないよう厳格な配慮 が求められる.

植物の駆除方法は, 人手および機械による方法, 化学 的方法, 生物学的方法, 生育地条件の改变による方法な どに分類される(Cronk \& Fuller 1995; Madsen 1997; Cronk \& Fennessy 2001; Wittenberg \& Cock 2001). これ らの駆除方法は, 対象とする植物種の生活史, 生態的特 性, 周囲に生育・生息する他の生物を考虑し, その場所 の状況に応じて適切なものを選択する必要がある。また， 同じ種であっても地方ごとの気候の違いなどにより，フ
エノロジー，すなわち，発茅，開花，結実の時期，ある いは地上部と地下部への物質分配の季節パターンなどが 異なるため，駆除時期については個別に検討を行うこと が必要である。

\section{1) 人手および機械による方法}

人手扔よび機械による方法には，植物体の抜き取り， 刈り取りなどがある，特に抜き取りは，対象とする外来 植物の選択的駆除が可能であるため, 他の方法と比較し て, 対象種以外の種への副次的影響が小さいという利点 がある (Wittenberg \& Cock 2001). また, 根系などの地 下部も含めた除去が確塞にできることも大きな利点とな 石.

一年生草本あるいは多年生草本・木本の実生など根の 浅い植物については, 根系を含めて植物体全体を抜き取 ることは，たやすいだけでなく効果も大きい(Wittenberg \& Cock 2001). しかし, 定着後数年経過した多年生草本 や木本の成木などの根系が地下媣くあるいは水平方向に 拡がっている植物に対しては, 別途, 根系の堀取りなど を実施する必要があるだろう。

なお，駆除対象とする外来植物が多年生草本であり， その種が優占群落を形成している場合には, 草刈機など を用いた刈り取りにより地上部の成長を抑制することも できる，その場合，効果的な刈り取りのためには，実施 時期の十分な検討が必要である. そのためには, 対象と する植物が地上部の刈り取りに対して示す反応（補償的 な成長, シュートの再生など）および地上部/地下部人 の物質分配の季節パターンに配慮する必要性がある(例 えば，富沢・黛谷 1998）。その際，刈り取りに対する植 物の物質分配やその他の生理生態学的反応に関するモデ ル（例えば, Iwasa \& Roughgarden 1984; Iwasa \& Cohen 1989）を用いて, 適切な刚り取り時期や頻度を検討する ことも有効である.

対象とする外来植物が木本の場合は, 根元付近からの 伐採が扔もな駆除手法となる，木本植物に対する繰り返 しの伐採は，根系に貯蔵した資源を消耗させ，枯死に至 らせる効果を持つ（Wittenberg \& Cock 2001）。ただし， 多くの種が伐採後再び萌芽するため, 伐採面 (切株) 一 除草剂などの薬剤を塗布するか，あるいは重機などを用 いた抜根が必要となる (Cronk \& Fuller 1995; Wittenberg \& Cock 2001). なお，切株処理に薬剤を用いる場合は “化学的方法”を用いる場合と同様, 薬剤による環境影 響を考慮する必要がある。

\section{2) 化学的方法}

化学物質すなわち除草剤等の使用は, 農地において最 
も一般的な害草駆除の方法となっている（伊藤 1993）. 農地に打计る駆除対象は，目的作物以外の不特定多数の 植物であり，そのために開発された除草郕は，特定の種 のみに効果を持つものではない．したがって，除草剤を 外来種駆除に用いた場合には，対象でない植物に対して もその影響が生じる。また，除草剤は，動物，微生物だ けでなく，人間に対して毒性を有するものも少なくない (Cronk \& Fuller 1995; Tu et al. 2001; Wittenberg \& Cock 2001). 生物多㥞性や水質の保全を併せて考慮すべき場所 に扔いて，対象を限定することのできない除草凨の使用 は問題が多いといえる（Cronk \& Fuller 1995; Tu et al. 2001).

\section{3）生物学的方法}

生物学的方法とは, 対象とする植物の天敵（例えば, その植物種を食べる昆虫や動物，病原菌）を用いて，そ の植物の成長を減少させる防除方法である，多くの場合， 生物学的方法によって, 対象とする植物を根絶させるこ とはできないため，その個体群を許容可能なレベルに抑 制するために用いられる(DeLoach 1997)。しかし，生物 学的方法の事例は, 成功よりも失敗, 寸なわ方防除効果 の認められなかった事例の方が多い (Williamson 1996).

また，天敵の導入に際しては，在来種や生態系への影 響に関する十分な事前評価が必要であるが，間接的影響 までを含めそれを予測・評価することは,・一般にきわめ て困難である (Simberloff \& Stiling 1996a; 日本生態学会 2002).

かつて生物学的方法は, 自然生態系に扔ける雑草管理 において，効果的で環境に対しても比較的安全な手法で あると考えられてきたが，生物学的方法のために導入し た生物が防除対象とした外来種以外の在来種や生態系に 対して，直接的あるいは間接的に影響を与える事例や可 能性が多く指摘されている (Simberloff \& Stiling 1996b; Louda et al. 1997; Cory \& Myers 2000). 予期しなかった 生態学的影響が生じている事例として, Louda \& O'Brien （2002）は，外来植物カナダアザミCirsium arvense (L.) Scop.の駆除のために導入した外来ゾウムシ Larinus planus Fabricius が，むしろ保全対象である在来アザミの 一種 Cirsium undulatum (Nutt.) Spreng. var. tracyi (Rydb.) Welshの種子生産を減少させていたことなどを報告して いる.

\section{4) 生育地条件の改変による方法}

外来植物の生育場所㧍よびその周辺の物理条件等を, 外来植物の生育に適さないかつての状態に復元すること も，駆除方法の選択肢となる。この方法の利点としては，
外来植物を除去しただけでは在来種を回復させることの できない場合，回復させるための生育条件の整備を駆除 と同時に行うことが挙げられる。例えば，ブルドーザー などを用いて, 表土とともに外来植物を取り除く方法(西 廣・皆川 2002；島谷 2003）が適用できる場合もある。

ただし，このような手法は，対象とする外来植物のみ を選択的に駆除するわけではないため，その場に生育. 生息する他の生物への影響を十分に考慮しなければなら ない。また，表土除去の結果生じた裸地に他の外来種が 侵入してくる可能性も考慮しなければならない（Randall et al. 1997).

外来植物シナダレスズメガヤが優占する鬼怒川の河原 においても，ブルドーザーを用いてシナダレスズメガヤ を根系ごと剥がす試験が実施されている(西廣・皆川 2002).ここでは, 絶滅危惧植物カワラノギク Aster kantoensis Kitam. 個体群の著しい衰退が確認されて扔り（村 中·塈谷 2001a)，緊急的な保全措置としてカワラノギク の系統を維持するための播種場所を造成するために，こ の試験が行われた（亘場ほか 2002；鷲谷 2003）。

本試験は, 絶滅危惧種保全のための人工河原造成の一 環として河原植物に関する生態学的知見を用いるたけで なく, 河川工学などの知見を総合して試験的に外来植物 を駆除するものである（萱場ほか 2002）。この試験では カワラノギク，カワラニガナIxeris tamagawaensis Kitam. などの河原に特有な植物の生育に適した砂嘫質河原を復 元するために，ポンプ車からの放水によって，シナダレ スズメガヤを剥がした後の地表から砂を除去するという 手法も用いられた（萱場ほか 2002）。これらのシナダレ スズメガヤ駆除手法は, 砂磼質河原へ砂の堆積が進行し ているという知見に加えて, 保全対象種であるカワラノ ギクおよびカワラニガナが永続的土壤シードバンクを形 成しない植物であり（倉本ほか 1994; Washitani et al. 1997; 本田·倉本 2001), そのため地表の砂を保全する必 要がないという判断に基づいて立案されたものである (西廣·皆川 2002)。

\section{市民・NPO 等との連携}

現在，日本の河川において実施されている外来種対策 は，市民のボランティア活動として実施されているもの も多い（例えば，小川 2000 ; 外来種影響・対策研究会 2001，2003）。また，植物を対象とし，“抜き取り”ゃ “朾り取り”を手法とする場合，市民・学童などの参加 を得やすい。そのような実践への参加を含めて, 外来植 
物対策の円滑な実施には市民の理解と協力が必要であり， そのためには小冊子などを用いた広報・啓発は重要であ る (Cronk \& Fuller 1995; 外来種影響 - 対策研究会 2001).

また，先述したように，河川における外来植物対策は， 流域の上流から下流までの広い地域を対象とした戦略の もとに進めていかなければ，効果を得ることが難しい. したがって，市民の協力を得ながら外来植物対策を進め ていく上では，地域間の連携が必要となる。

\section{おわりに}

日本の河川にはすでに多くの外来植物が侵入し，広い 生育地面積を占めるに至っているが，その大部分はたか たか 20 種程度の侵略的外来植物が優占する群落で占め られていることが明らかになった（Fig. 2$)$ ）これら，七 イタカアワダチソウ，ハリエンジュ，カモガヤ，才オブ タクサ，オオアワダチソウなどといった種は，日本の河 川における “警戒種”として優先的に外来植物対策の対 象とすべきである。

実践に打いては，市民の参加・協力が得られれば，外 来植物対策はより效果的に進められるだろう。しかし， 外来植物群落が広範に拡がっている河川に拈いては，市 民参加によるボランタリーな活動だけでは，根絶に必要 な労力が不足する可能性がある。また, 侵入・拡大要因 の根本的な解決には，河川における様々な物理条件を変 える必要がある場合もあるだろう。

このようなことを考慮すると，河川における外来植物 対策は，市民の協力の下，自然再生事業など河川環境の 保全に関わる事業の一環として，例えば絶滅危惧種の保 全と一体のものとして進めていくことが必要だろう。

\section{摘 要}

日本の河川において外来植物の侵入が進行している. 国が管理する河川において，外来植物群落の占める面積 の割合はすでに約 $15 \%$ に及び，その大部分はわずか数種 類の “侵略的外来植物”の群落によって占められている.

このような外来植物の侵入は，生物多様性に対する大 きな劦威であるだけでなく，生態系を全く異質なものに 変えてしまう可能性を持っている。 そして，外来植物侵 入によって生物多椂性や生態系へもたらされる変化は, 不可逆的なものである可能性がある。したがって，生物 多様性抢よび健全な生態系を保全するためには，早急に 外来植物対策を進める必要がある。
一方で，外来植物対策を成功させるためには，自然再 生事業などといった生態系管理の一環として対策を位置 つけりことが重要である。また，1）可能な限り外来種侵 大後の早い段階で対策を開始し，2）根絶のために十分 な労力を集中させ，3）対策自体がその他の生物や生態 系に与える影響を極力小さくし，4）生態的な復元と併 せて実施し，5）広域・長期的視点に立ち，順応的管理 手法に基づいて実施することが必要である.

そのためには，外来植物の土潩シードバンク特性をは じめとする生活史および個体群動態などといった生態学 的特性，侵入・分布拡大を助長する要因を明らかにする 必要がある。さらに，駆除方法の設定においても，管理 の戦略にもとづき環境負荷の小さい方法を潠ぶだけでな く，より効果が得られるような実施タイミングを選ぶよ うにしなければならない。このとき, 外来種の生態学的 知見だけでなく，周辺に生育・生息する生物，河川工学 などさまざまな専門分野の知見を統合する試みが必要で ある。

さらに，広域・長期的な戦略に基づく外来植物管理の ためには，そ秃ぞれの地域の市民・NPOなどが個別に対 策を実施するのではなく，流域内の他地域の主体との連 携のもとに対策を進めることが不可欠である。

\section{引用文献}

Agriculture and Resource Management Council of Australia and New Zealand, Australian and New Zealand Environment and Conservation Council \& Forestry Ministers (1999) National Weeds Strategy: A Strategic Approach to Weed Problems of National Significance in Australia.

http://www.affa.gov.au/index.cfm（2003 年 1 月 8 日）.

安島美穂 (2001) 埋土種子集団への外来種種子の蓄積. 保全 生態学研究 $6: 155-177$.

荒木佐智子・安島美穂・鹳谷いづみ（2003）土壤シードバン クを自然再生事業に活かす。「自然再生事業」(熟谷いづみ. 草刈秀紀編), pp. 187-211. 築地宣館, 東京.

Ashton P. J. \& Mitchell D. S. (1989) Aquatic plants: Patterns and modes of invasion, attributes of invading species and assessment of control programmes. In: Biological Invasion: A Global Perspective (eds. J. A. Drake, H. A. Mooney, F. di Castri, R. H. Groves, F. J. Kruger, M. Rejmánek \& M. Williamson), pp. 111-154. John Wiley \& Sons, Chichester.

Blossey B. (1999) Before, during and after: The need for longterm monitoring in invasive plant species management. Biological Invasions 1: 301-311.

Busch D. E. \& Smith S. D. (1995) Mechanisms associated with decline of woody species in riparian ecosystems of the Southwestern U.S. Ecological Monographs 65: 347-370.

Byers J. E., Reichard S., Randall J. M., Parker I. M., Smith C. S., Lonsdale W. M., Atkinson I. A. E., Seastedt T. R., Williamson M., Chornesky E. \& Hayes D. (2002) Directing research to re- 
duce the impacts of nonindigenous species. Conservation Biol ogy 16: $630-640$.

Campbell G. S., Blackwell P. G. \& Woodward F. I. (2002) Can landscape-scale characteristics be used to predict plant invasions along rivers?. Journal of Biogeography 29: 535-543.

Conner W. H., Gosselink J. G. \& Parrondo R. T. (1981) Comparison of the vegetation of three Louisiana swamp sites with different flooding regimes. American Journal of Botany 68: 320331.

Cory J. S. \& Myers J. H. (2000) Direct and indirect ecological effects of biological control. Trends in Ecology \& Evolution 15: $137-139$.

Cronk C. B. \& Fuller J. L. (1995) Plant Invaders: The Threat to Natural Ecosystem. Chapman \& Hall, London.

Cronk J. K. \& Fennessy M. S. (2001) Wetland Plants: Biology and Ecology. Lewis Publishers, Boca Raton.

Curnutt J. (2000) Host-area specific climatic-matching: similarity breeds exotics. Biological Conservation 94: 341-351.

DeLoach C. J. (1997) Biological control of weeds in the United States and Canada. In: Assessment and Management of Plant Invasions (eds. J. O. Luken \& J. W. Thieret), pp. 179-194. Springer. New York.

di Castri F. (1989) History of biological invasions with special emphasis on the old world. In: Biological Invasion: A Global Perspective (eds. J. A. Drake, H. A. Mooney, F. di Castri, R. H. Groves, F. J. Kruger, M. Rejmánek \& M. Williamson), pp. 130. John Wiley \& Sons, Chichester.

Doak D. F., Thomson D. \& Jules E. S. (2002) Population viability analysis for plants: Understanding the demographic consequences of seed banks for population health. In: Population Viability Analysis (eds. S. R. Beissinger \& D. R. McCullough), pp. 312-337. The University of Chicago Press, Chicago.

Drayton B. \& Primack R. B. (1999) Experimental extinction of garlic mustard (Alliaria petiolata) populations: implications for weed science and conservation biology. Biological Invasions 1:159-167.

Drake J. A., Mooney H. A., di Castri F., Groves R. H., Kruger F. J., Rejmanek M. \& Williamson M. (eds.) (1989) Biological Invasion: A Global Perspective. John Wiley \& Sons, Chichester.

El-Ghareeb. R. (1991) Vegetation and soil changes induced by Mesembryanthemum crystallinum L. in a Mediterranean desert ecosystem. Journal of Arid Environments 20: 321-330.

Ewel K. C. (1986) Invasibility: Lessons from South Florida. In: Ecology of Biological Invasions of North America and Hawaii (eds. H. A. Mooney \& J. A. Drake), pp. 214-230. Springer-Verlag, New York.

藤田正憲 - 森本和花 · 河野宏樹 - Silvana Perdomo - 森一博 池道彦・山口克人 物田訓 $(2001)$ 水質浄化に利用可能な 植物データベースの構築. 環境科学会誌 14:1-13.

Franz E. H. \& Bazzaz F. A. (1977) Simulation of vegetation response to modified hydrologic regimes: A probabilistic model based on niche differentiation in a floodplain forest. Ecology 58: 176-183.

外来種影響・対策研究会（2001）河川における外来種対策に 向けて [案].リバーフロント整備センター，東京.

外来種影響・対策研究会 (2003) 河川に扔ける外来種対策の 考え方とその事例一主な侵略的外来種の影響と対策一。
バーフロント整備センター, 東京.

Gould W. A., Walker M. D. (1997) Landscape-scale patterns in plant species richness along an arctic river. Canadian Journal of Botany 75: 1748-1765.

Grime J. P. (1979) Plant Strategies and Vegetation Processes. Wiley, Chichester.

Groves R. H. (1989) Ecological control of invasive terrestrial plants. In: Biological Invasion: A Global Perspective (eds. J. A. Drake, H. A. Mooney, F. di Castri, R. H. Groves, F. J. Kruger, M. Rejmanek \& M. Williamson), pp. 437-461. John Wiley \& Sons, Chichester.

Hanski I. (1999) Metapopulation Ecology. Oxford University Press, New York.

Hanski I. \& Gilpin M. E. (eds.) (1996) Metapopulation Biology: Ecology, Genetics, and Evolution. Academic Press, San Diego.

Hobbs R. J. \& Humphries S. E. (1995) An integrated approach to the ecology and management of plant invasions. Conservation Biology 9: 761-770.

Hobbs R. J. (2000) Land-use changes and invasions. In: Invasive Species in a Changing World (eds. H.A. Mooney and R.J. Hobbs), pp. 55-64. Island Press. Washington, D. C.

本田裕紀郎・萝本宣 (2001) 多摩川に打ける絶滅危惧植物力 ワラニガナの現状とその休眠・発芽特性. ランドスケープ 研究 64: 583-588.

飯島章彦 (1999) リンゴ炭㾝病の発生生態と防除. 植物防疫 53:253-256.

伊藤操子 (1993) 雑草学概論. 養賢堂, 東京.

Iwasa Y. \& Cohen D. (1989) Optimal growth schedule of a perennial plant. The American Naturalist 133: 480-505.

Iwasa Y. \& Roughgarden J. (1984) Shoot/root balance of plants: Optimal growth of a system with many vegetative organs. Theoretical Population Biology 25: 78-105.

Johnson W. C., Burgess R. L. \& Keammerer W. R. (1976) Forest overstory vegetation and environment on the Missouri river floodplain in North Dakota. Ecological Monographs 46: 59-84.

Kalisz S. \& McPeek M. A. (1992) Demography of an age-structured annual : Resampled projection matrices, elasticity analysis, and seed bank effects. Ecology 73: 1082-1093.

環境省編（2002）新・生物多様性国家戦略：自然の保全と再 生のための基本計画。ぎょうせい.

葍場祐一（2000）零石川におけるハビタットの変化と冠水頻 度との関連について. 環境システム研究論文集 28 : 347 352.

萱場祐一、千葉武生 · 力山基 (2002) 鬼怒川に扔けるカワラ ノギク保全のための人工河原造成について，土木学会第 57 回年次学術講演会 VII-058: 115-116.

建設省河川局河川環境課（1996）平成 5 年度（BOOK \& CDROM）河川水辺の国勢調查年鑑植物調查編. 山海堂, 東京. 建設省河川局河川環境課 (1997a) 平成 6 年度 (BOOK \& CD$\mathrm{ROM}$ ）河川水辺の国勢調查年鑑（河川版）植物調查編.山 海堂, 東京.

建設省河川局河川環境課 (1997b) 平成 7 年度 (BOOK \& CD$\mathrm{ROM}$ ）河川水辺の国势調査年鑑（河川版）植物調査編.山 海堂, 東京.

建設省河川局河川環境課（1997c）平成 9 年度河川水辺の国勢 調查マニュアル河川版 (生物調查編)。財団法人リバーフ ロント整備センター, 東京. 
建設省河川局河川環境課 (1998) 平成 8 年度 (BOOK \& CD$\mathrm{ROM}$ ) 河川水辺の国勢調查年鑑（河川版）植物調査編。山 海堂, 東京.

建設省河川局河川環境課（1999）平成 9 年度（BOOK \& CD$\mathrm{ROM}$ ）河川水辺の国勢調查年鑑（河川版）植物調査編. 山 海堂, 東京.

建設省河川局河川環境課 $(2000)$ 平成 10 年度 (BOOK \& CD$\mathrm{ROM}$ ) 河川水辺の国勢調査年鑑（河川版）植物調査編.山 海堂, 東京.

建設省河川局治水課（1994）平成 3 年度河川水辺の国勢調査 年鑑底生動物調查, 植物調査, 鳥類調査, 而生類·爬虫類・ 哺乳類調查, 陸上昆虫類等調査編. 山海堂, 東京.

建設省河川局治水課（1995）平成 4 年度河川水辺の国勢調査 年鑑植物調查編。山海堂，東京.

国土交通省北陸整備局千曲川工事事務所（2003）千曲川・姩 川のアレチウリ：河川の自然を保全するための外来植物対 策. http://210.131.8.12/ tikuma/index.html (2003 年3月 10 日).

国土交通省河川局河川環境課 (2001) 平成 11 年度 (BOOK \& $\mathrm{CD}-\mathrm{ROM}$ ) 河川水辺の国勢調查年鑑 (河川版)植物調查編. 山 海堂, 東京.

Kolar C. S. \& Lodge D. M. (2000) Freshwater nonindigenous species: interactions with other global changes. In: Invasive Species in a Changing World (eds. H.A. Mooney and R.J. Hobbs), pp. 3-30. Island Press. Washington, D. C.

倉本宣・并上健・既谷いづ (1993) 多摩川中流の流水辺に おける河辺植生構成種の分布特性についての研究. 造園雑 誌 56: 163-168.

倉本宣・䴙谷いつみ·牧雅之・増田理子・井上健（1994）多 摩川におけるカワラノギクの種子期の動態. 造園雑誌 57: 127-132.

Le Maitre D. C., van Wilgen B. W., Chapman R. A. \& McKelly D. H. (1996) Invasive plants and water resources in the Western Cape Province, South Africa: modeling the consequence of a lack of management. Journal Applied Ecology 33: 161-172.

Le Maitre D. C., Versfeld D. B. \& Chapman R. A. (2000) The impact of invading alien plants of surface water resources in South Africa: A preliminary assessment. Water SA 26: 397408.

Leck M. A. , Parker V. T. \& Simpson R. L. (eds.) (1989) Ecology of Soil Seed Banks. Academic Press, San Diego.

Lindsey A. A, Petty R. O., Sterling D. K. \& van Asdall W. (1961) Vegetation and environment along the Wabash and Tippecanoe Rivers. Ecological Monographs 31: 105-156.

李参熙・藤田光一・山本晃一（1999）啋床河道における安定 植生拡大のシナリオ一多摩川上流部を対象とした事例分析 より一. 水工学論文集 43: 977-982.

Louda S. M., Kendall D., Connor J. \& Simberloff D. (1997) Ecological effects of an insect introduced for the biological control of weeds. Science 277: 1088-1090.

Louda S. M. \& O'Brien C. W. (2002) Unexpected ecological effects of distributing the exotic weevil, Larinus planus (F.), for the biological control of Canada thistle. Conservation Biology 16: $717-727$.

Luken J. O. \& Thieret J. W. (eds.) (1997) Assessment and Management of Plant Invasions. Springer. New York.

MacDonald I. A. W., Loope L. L., Usher M. B. \& Hamann O. (1989) Wildlife conservation and the invasion of nature reserves by introduced species: A global perspective. In: Biological Invasion: A Global Perspective (eds. J. A. Drake, H. A. Mooney, F. di Castri, R. H. Groves, F. J. Kruger, M. Rejmánek \& M. Williamson), pp. 215-256. John Wiley \& Sons, Chichester.

Mack M. C. \& D'Antonio C. M. (1998) Impacts of biological invasions on disturbance regimes. Trends in Ecology \& Evolution 13: 195-198.

Mack R. N., Simberloff D. S., Lonsdale W. M., Evans H., Clout M. \& Bazzaz F. A. (2000) Biotic invasions: causes, epidemiology, global consequences, and control. Ecological Applications 10: $689-710$.

Madsen J. D. (1997) Methods for management of nonindigenous aquatic plants. In: Assessment and Management of Plant Invasions (eds. J. O. Luken \& J. W. Thieret), pp. 145-171. Springer. New York.

Matsumoto J., Muraoka H. \& Washitani I. (2000) Whole plant carbon gain of an endangered herbaceous species Aster kantoensis and the influence of shading by an alien grass Eragrostis curvula in its gravelly floodplain habitat. Annals of Botany 86: 787-797.

McNeely J. A., Mooney H.A., Neville L. E., Schei P. J. \& Waage J. K. (eds.) (2001) Global Strategy on Invasive Alien Species. IUCN, Gland, Switzerland, and Cambridge, UK.

Menges E. S. (2000) Applications of population viability analyses in plants conservation. Ecological Bulletins 48: 73-84.

宮脇成生・熟谷いづみ（1996）土塨シードバンクを考慮した 個体群動態モデルと侵入植物オオブタクサの駆除効果の子 測. 保全生態学研究 $1: 25-47$.

Mooney H. A. \& Drake J. A. (eds.) (1986) Ecology of Biological Invasions of North America and Hawaii. Springer-Verlag, New York.

Mooney H. A. \& Hobbs R. J. (eds.) (2000) Invasive Species in a Changing World. Island Press. Washington, D.C.

村上興正 - 鷿谷いづみ (2002) 外来種と外来種問題.「外来種 ハンドブック」(日本生態学会編), pp. 3-4. 地人書館, 東京.

村中孝司・熟谷いづみ(2001a) 鬼怒川砂磁質河原に打外外 来牧草シナダレスズメガヤの侵入と河原固有植物の急激な 減少: 緊急对策の必要性. 保全生態学研究 6:111-122.

村中孝司・炁谷いつみ (2001b) 鬼怒川砂磁質河原の植生と外 来植物の侵入. 応用生態工学 4:121-132.

Myers J. H., Simberloff D. S., Kuris A. M. \& Carey J. R. (2000) Eradication revisited: dealing with exotic species. Trends in Ecology \& Evolution 15: 316-320.

中坪孝之（1997）河川汇濫原におけるイネ科帰化草本の定着 とその影響. 保全生態学研究 2:179-187.

西廣淳・皆川朋子（2002）河川に侵入した外来植物の駆除・ 管理。土木技術資料 44(10): 50-55.

西田智子 (2002) 飼料畑・草地における外来雑草の侵入一外 来雑草の飼料畑・草地への侵入と夢延一. Grassland Science 48: 168-176.

日本生態学会編（2002）外来種ハンドブック。地人書館, 東 京.

日本緑化工学会 (2002) 生物多様性保全のための緑化植物の 取り扱い方に関する提言. 日本緑化工学会誌 27：481-491. 小川早枝子 (2000) 私たちのフイールドの汇濫原でオオブタ クサが激減した（概要）生物多様性の維持管理一外来植物 
加在来希少植物を守る。多自然研究 1 月号 (第 52 号): $31-35$.

Parker I. M. (2000) Invasion dynamics of Cytisus scoparius: A matrix models approach. Ecological Applications 10: 726-743.

Pimentel D., Lach L., Zuniga R. \& Morrison D. (2000) Environmental and economic costs of nonindigenous species in the United States. BioScience 50: 53-65.

Pimentel D., McNair S., Janecka J., Wightman J., Simmonds C., O'Connell C., Wong E., Russel L., Zern J., Aquino T. \& Tsomondo T. (2001) Economic and environmental threats of alien plant, animal, and microbe invasions. Agriculture, Ecosystems and Environment 84: 1-20.

Primack R. B. (1993) Essentials of Conservation Biology. Sinauer Associates, Massachusetts.

Pulliam H. R. (1988) Sources, sinks, and population regulation. The American Naturalist $132: 652-661$.

Randall J. M., Lewis III R. R. \& Jensen D. B. (1997) Ecological restoration. In: Stranger in Paradise: Impact and Management of Nonindigenous Species in Florida (eds. D. Simberloff, D.C. Schmitz \& T.C. Brown), pp. 206-220. Island Press, Washington D.C.

斉藤洋三. 井手武 (1994) 花粉症の科学. 化学同人, 京都.

Schmitz D. C., Simberloff D., Hofstetter R. H., Haller W. \& Sutton D. (1997) The ecological impact of nonindigenous plants. In: Stranger in Paradise: Impact and Management of Nonindigenous Species in Florida (eds. D. Simberloff, D. C. Schmitz \& T. C. Brown), pp. 39-61. Island Press, Washington D. C.

Schneider R. L. \& Sharitz R. R. (1988) Hydrochory and regeneration in a bald cypress -water tupelo swamp forest. Ecology 69: 1055-1063.

島谷幸宏 (2003) 多摩川永田地区の河道修復. 応用生態工学 5:233-240.

Silvertown J. \& Charlesworth D. (2001) Introduction to Plant Population Biology. 4th Ed. Blackwell Science, Oxford.

Simberloff D. (1997) Eradication. In: Stranger in Paradise: Impact and Management of Nonindigenous Species in Florida (eds. D. Simberloff, D.C. Schmitz \& T.C. Brown), pp. 221228. Island Press, Washington D. C.

Simberloff D. (2003) How much information on population biology is needed to manage introduced species? Conservation Biology 17: 83-92.

Simberloff D. \& Stiling P. (1996a) Risks of species introduced for biological control. Biological Conservation 78: 185-192.

Simberloff D. \& Stiling P. (1996b) How risky is biological control? Ecology 77: 1965-1974.

清水矩宏（2000）新たに侵入している強害外来雑草の農耕地 ヘのインパクト.生物科学 52(1): 17-28.

清水義彦·小葉竹重機・岡田理志・新船隆行 · 岩崎工 (2000) 洪水擋乱によるハリエンジュの破壊 - 再生と河道内樹林化 について．河川技術に関する論文集 6:59-64.

清水義彦 ·長田健吾（2002）砂床河川に打ける河道内樹林地 の洪水破壞について。河川技術論文集 8: 301-306.

Simpson R. L., Leck M. A. \& Parker, V. T. (1989) Seedbanks: general concepts and methodological issues. In: Ecology of Soil Seed Banks (eds. M. A. Leck, V. T. Parker \& R. L. Simpson), pp. 3-8. Academic Press, San Diego, California.

Staniforth R. J. \& Cavers P. B. (1976) An experimental study of water dispersal in Polygonum spp. Canadian Journal of Botany 54: 2587-2596.

末次忠司 (2002) 洪水流と土砂動態との相互作用（その 1$)$. 水利科学 $45(6)$ : 33-51.

末次忠司・服部敦・瀬崎智之（2001）洪水攪乱に伴う植生の 変化一千曲川を例にとって一. 水利科学 45(4)：33-47.

The Working for Water Programme (2000) Annual Report 1998/99. http://www.dwaf.gov.za/wfw/AnnualReports/ (2002 年 12 月 22 日).

The Working for Water Programme (2001) Annual Report 1999/2000. http:/www.dwaf.gov.za/wfw/AnnualReports/ (2002 年 12 月 22 日).

The Working for Water Programme (2002) Annual Report 2000/1. http://www.dwaf.gov.za/wfw/AnnualReports/（2002 年 12 月 22 日).

Thompson K. \& Grime J. P. (1979) Seasonal variation in the seed banks of herbaceous species in ten contrasting habitats. Journal of Ecology 67: 893-921.

富沢美和・臽谷いづみ（1998）フジバカマとセイタカアワダ チソウの夏季に招ける地上部䘫失に対する反応一復元植生 の管理計画を立てるために一。保全生態学研究 3: 57-67.

Tu M., Hurd C. \& Randall J. M. (2001) Weed Control Methods Handbook: Tools and Techniques for Use in Natural Areas. The Nature Conservancy.

http://ncweeds.ucdavis.edu/handbook.html (2003 年 2 月 11 日).

UNEP (2002) Decisions Adopted by the Conference of the Parties to the Convention on Biological Diversity at its sixth meeting. UNEP/CBD/COP/6/20.

http://www.biodiv.org/doc/decisions/cop-06-dec-en.pdf (2003年 12 月 21 日)

浦和市教育委員会 (2001) 特別天然記念物田島ヶ原开クラソ 门自生地保護增殖実験調査事業報告書 (平成 12 年度).

Usher M. B. (1988) Biological invasions of nature reserves: A search for generalizations. Biological Conservation 44: 119-135. van Wilgen B. W. \& Richardson D. M. (1985) The effects of alien shrub invasions on vegetation structure and fire behaviour in South African fynbos shrublands: A simulation study. Journal of Applied Ecology 22: 955-966.

van Wilgen B. W., Le Maitre D. C. \& Cowling R.M. (1998) Ecosystem services, efficiency, sustainability and equity: South Africa's Working for Water programme. Trends in Ecology \& Evolution 13: 378.

Vitousek P. M. (1986) Biological invasions and ecosystem properties: Can species make a difference?. In: Ecology of Biological Invasions of North America and Hawaii (eds. H. A. Mooney \& J. A. Drake), pp. 163-176. Springer-Verlag, New York.

Vitousek P. M., Walker L. R., Whiteaker L. D., Mueller-Dombois D. \& Matson P. A. (1987) Biological invasion by Myrica faya alters ecosystem development in Hawaii. Science 238: 802-804.

Vitousek P. M., D'Antonio C. M., Loops L. L. \& Westbrooks R. (1996) Biological invasions as global environmental change. American Scientist 84: 468-478.

鷲谷いづみ（1993）生物多様性の保全と絶滅危惧植物の繁殖 生態. 個体群生態学会会報 50：19-26.

鸛谷いづみ（1997）保全生態学と個体群動態：種子植物の場 合. 日本生態学会誌 47: 185-187. 
熟谷いづみ（1998）生態系管理における順応的管理. 保全生 態学研究 3: 145-166.

鷿谷いずみ (1999) 生物保全の生態学, 共立出版, 東京.

鷿谷いづみ $(2000 \mathrm{a})$ 外来植物の管理. 保全生態学研究 5: 181 $-185$.

熟谷いづみ (2000b) 生物多様性を妿かす「緑の」生物学的侵 入. 生物科学 $52: 1-6$.

Washitani I. (2001) Plant conservation ecology for management and restoration of riparian habitats of lowland Japan. Population Ecology 43: 189-195.

鶌谷いづ (2002a) 不可逆的に生態系が变化した時代：外来 植物の侵入。科学 72: 77-83.

䴙谷いつみ $(2002 \mathrm{~b})$ 緑化による外来牧草の侵入.「外来種八 ンドブック」(日本生態学会編), pp. 46-47. 地人書館, 東 京.

䳡谷いづみ(2003) 今なぜ自然再生事業なのか.「自然再生事 業」(䉆谷いづみ. 草刈秀紀編), pp. 2-42. 築地書館, 東 京.

Washitani I., Takenaka A., Kuramoto N. \& Inoue K. (1997) Aster kantoensis Kitam., an endangered flood plain endemic plant in Japan: Its ability to form persistent soil seed banks. Biological Conservation 82: 67-72.

鷲谷いづみ・村上興正（2002）外来種対策に関する基本的な 考え方.「外来種ハンドブック」(日本生態学会編), pp. 39
-41. 地人書館, 東京.

留谷いづみ・森本信生（1993）日本の帰化生物。保育社, 大 阪.

熟谷いづみ・矢原微一（1996）保全生態学入門。文一総合出 版, 東京.

既谷いづみ・松田裕之（1998）生態系管理および環境影響評 価に関する保全生態学からの提言 (案). 応用生態工学 1: 51-62.

Williamson M. (1996) Biological Invasions. Chapman \& Hall, London.

Wilson S. D. (1989) The suppression of native prairie by alien species introduced for revegetation. Landscape Urban Planning 17: 113-119.

Wittenberg R. \& Cock M. J. W. (eds.) (2001) Invasive Alien Species: A Toolkit of Best Prevention and Management Practices. $\mathrm{CAB}$ International, Wallingford.

矢野悟道編（1988）日本の植生：侵略と攪乱の生態学. 東海 大学出版会, 東京.

米森由佳・倉本宣（2000）多摩川に扮ける増水による種子散 布と増水後の護岸植生についての研究. ランドスケープ研 究 63: 527-530.

Zavaleta E. S., Hobbs R. J. \& Mooney H. A. (2001) Viewing invasive species removal in a whole-ecosystem context. Trends in Ecology \& Evolution 16: 454-459. 